\title{
大腸㕷室症手術症例の検討
}

\author{
防衛医科大学校第 1 外科 \\ 長谷 和生 望月 英隆 山本 哲久 \\ 加賀田 豊 王熊 正悦

\section{STUDY OF SURGICAL TREATMENT FOR DIVERTICULAR DISEASE OF THE COLON}

\section{Kazuo HASE, Hidetaka MOCHIZUKI, Tetsuhisa YAMAMOTO, Yutaka KAGATA and Shoetsu TAMAKUMA} \\ First Department of Surgery, National Defense Medical College
}

防医大 1 外開設以来 8 年半に行った注腸造影 1,053 例中 140 例（13.3\%）に大腸䕀室を認めた，大腸 の部位では右側型 $58.6 \%$, 左側型 $30.0 \%$, 両側型 $11.4 \%$, 本邦での従来の報告に比べ左側型が多く, しかもその左側型では加齢とともに発見頻度が増加する傾向を認めた。このうち22例 (15.7\%) に手 術を行ったが, 手術適応となった香室合併症では反復する䅣室炎と穿孔が最も多く, 次いで膿瘍形成, 狭窄，下血であった。穿孔例 6 例中 5 例に対して 1 期的に腸切除・吻合術を行い，術後経過は順調で あった．右側型の膿湯形成例には主として腸切除を行い良好な結果を得たが，選択すべき術式につい ては誘導術のみの術式とのさらなる比較検討が今後必要である。

系引用語：大腸悡室症, 大腸息室合併症, 大腸悡室症の手術適応

はじめに

近年本邦に和ける大腸憩室症は高齢者の増加, 食生 活の欧米化，大腸 $\mathrm{X}$ 線診断技術の進歩などに伴って, その発見頻度が増加しつつある1) 7). それとともに従 来は明確な診断がつきにくかった種々の腹部愁訴が憩 室症との関連で病態が明確にされており, 本症の臨床 的意義は一段之大さくなっている，一方，本症に合併 症が併発した際には毠室の局在, 数, 炎症や出血の程 度などによって治療方針を変える必要性が指摘さ れ3)4)6) 13), 手術適応や選択すべき術式については今な 扣議論のあるところである。今回大腸嚊室症の自験例 140例を対象に検討を行い, 㮩室手術症例22例をるとに 㮩室合併症に対する手術適応，選択すべき術式などに ついても考察を加壳た。

対象, 結果

昭和 54 年. 1 月の当科診療開始以来昭和 61 年 6 月まで の 8 年半の間に当科で施行した注腸造影 1,053 例中, 憩 室を認めた140例を対象とした。発見頻度は $13.3 \% て ゙ ，$

$<1987$ 年 6 月 8 日受理 $>$ 別刷請求先 : 長谷 和生 干 359 所沢市並木 $3-2$ 防衛医科大学校第 1 外科
表 1 大腸憩室症の年齢別発見頻度

\begin{tabular}{|c|c|c|c|}
\hline 年唩 & 注㘧造影例数 & 䛱室症例数 & $\%$ \\
\hline ～39才 & 226 & 17 & 7.5 \\
\hline $40 \sim 59$ & 451 & 55 & 12.2 \\
\hline 60 & 376 & 68 & 18.1 \\
\hline It & 1053 & 140 & 13.3 \\
\hline
\end{tabular}

これを性別にみると男75例(15.0\%)，女65例(11.8\%) であった。年齢別発見頻度は39歳以下 $7.5 \%, 40$ ～59歳 $12.2 \%, 60$ 歳以上 $18.1 \%$ ありり，加㱓とともに増加す る傾向を認めた（表 1 ）。

唕室の発生部位は, 横行結腸を含む右側型が82例 (58.6\%), 左側型42例 (30\%), 両側型16例 $(11.4 \%)$ であり，性差を認めなかった(図 1 )。憩室発見頻度を 発生部位別・年秢別にみると, 右側型では発見頻度に 年淽層による明確な傾向を認めなかったが, 左側型で は加齢之ともに発見頻度が増加する傾向が認められ， 表 1 の大腸息室全体の加㱓による発見頻度の増加は, 主に左側型の増加によるものと考えられた(図 2 ). 憩 室の個数と発生部位との関係は表 2 のうに, 右側型 では単発型と多発型が注注同数であるのに対し, 左側 型では多発型が約 $2 / 3$ 占め, 左側型に多発憩室が多い 
図 1 大腸唕室症と発生部位

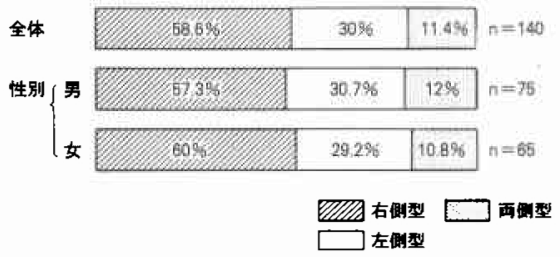

図 2 大腸喤室症の発生部位別・年龄別発見頻度

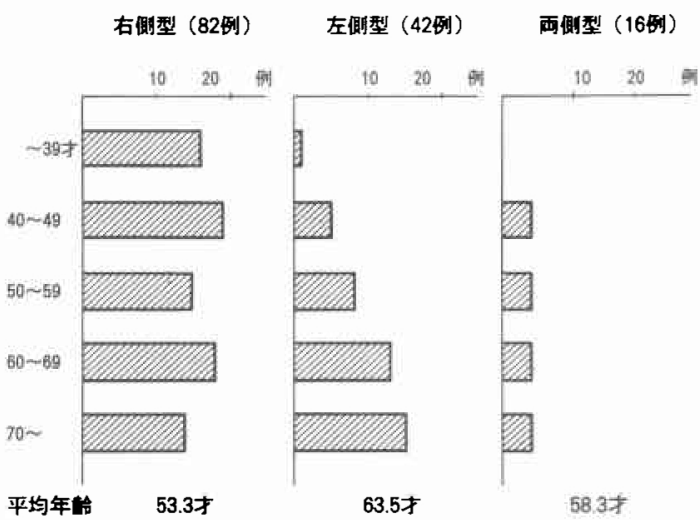

表 2 大腸䕀室症の部位と個数

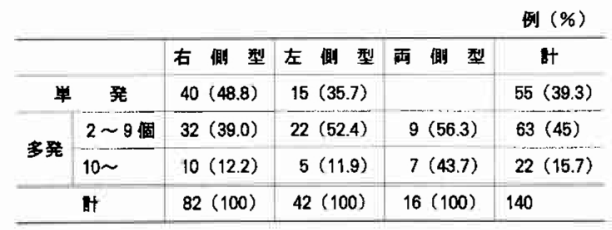

傾向がうかがわれた。

140例の自験例中手術を施行した喤室症例は22例，

15.7\%であったが，これらの覕室の発生部位では，右 側型が14例 $(63.6 \%)$, 左側型が 6 例 $(27.3 \%)$, 両側 型が 2 例 (9.1\%) であった。年齢別に比較すると左側 型の手術例はすべてが50歳以上で，しかも 6 例中 3 例 が70歳以上であったのに対し，50歳未満の手術症例は 1 例を除いてすべてが右側型であった，50歳を境に手 術症例数を右側型, 左側型で対比すると，両者間には 有意の差 $(\mathrm{p}<0.01)$ を認め, また両者間には平均年齢 で約16歳の差がみられた（図 3 )。

手術適応となった秝室合併症で最も多くみられたの は穿孔，礊室炎で，おのおの 6 例 $(27.3 \%)$ のあせ て12例，次いで膿瘍形成，狭窄がおの㧍の 4 例 (18.2\%) ずつ，下血が 2 例 (9.1\%) に認められた．部位別に検
図 3 大腸覟室手術症例之年齢分布

右溉型 (14例) 左㑡型（6 例）禹側型（2 例）

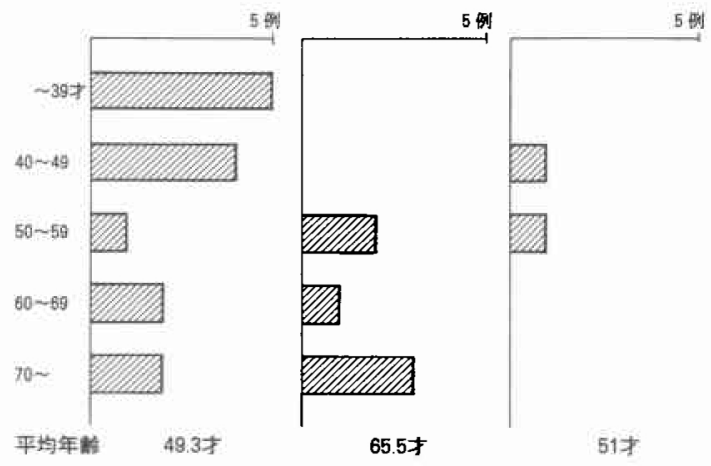

図 4 手術の原因となった憩室合併症

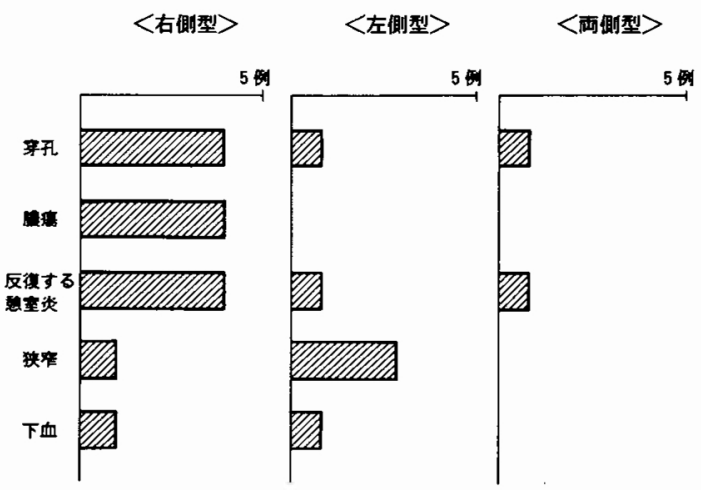

討すると，右側型では穿孔，膿湯形成，反復する惒室 炎が扔の扮の 4 例ずつみられ多彩であったが，狭窄例

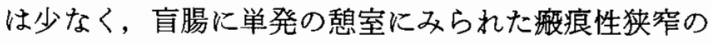
1 例の反であった。これに対し左側型では狭窄を呈す るわのが多く，半数の 3 例にみられ，いずれもイレウ スを呈していた。穿孔した 6 例中 4 例は右側型で，そ の 4 例中 1 例は術前の腹部単純 X 線上 free air め, 手術時腹腔内に約 $1,000 \mathrm{ml}$ の出血を認めた症例で あった（図 4 ).

術前診断を誤った例は，急性虫垂炎としたものが 5 例と多く，次いで狭窄の 4 例であった，後者のらちイ レウス症状を呈し，救急手術を行なった 3 例はすべて 左側型であり，狭窄を呈する左側型㮩室の術前診断は 容易ではなかった（表 3 ）。

右側型に対する手術は，小膿場形成の1例に対して は㮩室切除術を，腫瘤を形成した膿瘍例，反復する㮩 室炎例，穿孔例などに対しては結腸切除を施行した。 
表 3 手術例の術前診断

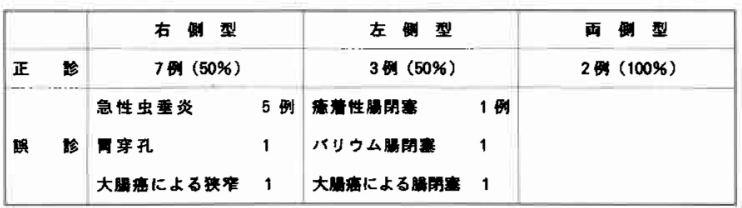

表 4 右側型の術式と予後

\begin{tabular}{|c|c|c|c|c|c|c|c|c|c|}
\hline 症 制 & 年賗・性 & 豈合拼主 & 手苚 & 時期 & 涉 式 & 街後 & 栟症 & $\mathbf{7}$ & 役 \\
\hline 1 & $38 \sigma^{7}$ & mistin & 覃 & & 甞室切除 & な & L & & \\
\hline 2 & $39 \sigma^{7}$ & 的率形成) & 堅 & 急 & & 皮下 & 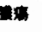 & & \\
\hline 3 & 32 우 & 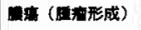 & 霖 & 急 & & な & し & & \\
\hline 4 & $410^{7}$ & 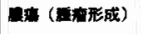 & 待 & 期 & & な & し & & 再 \\
\hline 5 & $728^{7}$ & 㲔 & 掔 & 急 & & な & $\iota$ & & \\
\hline 6 & $390^{x}$ & 穿れ & 柴 & 急 & & な & c & & 燃 \\
\hline 7 & 489 & 芽孔 & 露 & 急 & 桔盟切除 & な & $\iota$ & & \\
\hline 8 & 87 우 & 来れ & 柴 & 急 & & な & $\iota$ & & な \\
\hline 9 & 47 o & 反復する颓宣炎 & 待 & 谟 & & な & し & & \\
\hline 10 & 378 & 反隻する利室炎 & 待 & 期 & & 5 & し & & し \\
\hline 11 & 40 o & 反復する悡军资 & 等 & 期 & & な & し & & \\
\hline 12 & $57 \sigma^{7}$ & 反得する瑟室炎 & 待 & 期 & & な & し & & \\
\hline 13 & 71 우 & 联寒 & 待 & 期 & & な & し & & \\
\hline 14 & 62 우 & 下血 & 特 & 期 & & な & L & & \\
\hline
\end{tabular}

表 5 左側型および両側型の術式と予後

\begin{tabular}{|c|c|c|c|c|c|c|c|}
\hline & 的 & 年鲙・性 & 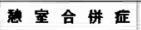 & 手街時期 & 武 & 徨绕合样理 & $\mp$ \\
\hline & $\overline{1}$ & $560^{x}$ & 穿 $れ$ & 卧 & 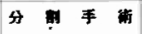 & ヘ工形 & \\
\hline 左 & 2 & $72+$ & 脐 & 果 & 分 手霖 & 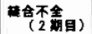 & 再 \\
\hline & 3 & 718 & 浃 & 畨 & S状精湭切除 & な L & 燃 \\
\hline [at] & 4 & 67 우 & 狭 & 知 & 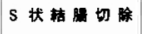 & な & な \\
\hline 唪 & 5 & $500^{7}$ & 反流する䍐室炎 & 等 期 & 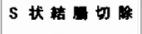 & 合不全 & し \\
\hline & 6 & 77 우 & 下 血 & 结 敭 & 低位蔽方の切瞵 & 皮下的 & \\
\hline 西 & 1 & $\begin{array}{l}48+7 \\
548\end{array}$ & $\begin{array}{l}\text { 反隻する息室炎 } \\
\text { 柴 }\end{array}$ & 待 期 & 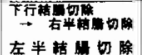 & $\begin{array}{l}\text { な し } \\
\text { な し }\end{array}$ & 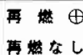 \\
\hline
\end{tabular}

術後経過は 1 例に皮下膿場を併発した以外は良好で， 術後に炎症などの再然を認めていない(表 4 ). 左側型 に対する手術では，穿孔例 1 例とイレゥスの 1 例に 2 期的手術を行ったが，その他の 4 例では緊急・待期の いかんを問わず 1 期的腸切除・吻合術を行い，5ち 1 例に縫合不全を認めた。両側型の 2 例のらち 1 例では 反復する憩室炎症状に対する下行結腸切除後, 反復性 の右側息室炎症状が出現のため，9 カ月後改めて同部 の結腸切除を施行した。 しかし再手術後も横行結腸秝 室炎の症状を頻回に訴之ている。す51例は下行結腸 㮩室穿孔に対する 1 期的左半結腸切除術の後, 良好に 経過し，経過観察中である（表 5 )。

\section{考察}

大腸秝室症は本邦に㧊いては比較的少ない大腸疾患 と考えられていたが14115)，1970年代になり大腸疾患に 対する関心の高をりや大腸 X 線診断技術の進歩など
により，発見頻度は増加しつつある。久保ら゙によれば 本症の平均発見頻度は，1965 68年には2.16\%であっ たが，1970７2年は5.36\%，1975～77年は $9.50 \% ， さ$ らに1978 80年は $12.37 \%$ 上昇し, 15年間に実に約 6 倍にも達したとい5。その他の最近の報告でも7 〜 12\%のものが多く2) ${ }^{21)}$, 自験例では13.3\%であった. このような増加には前記の原因のほかに，高齢者の増 加之, 食事内容の欧米化すなわち食䬣性紼維の摄取量 の低下も指摘されている5゙が，欧米に扔ける発見頻度 は22 45\%と報告されており年，いまだに本邦とは大 きな差を認める。

憩室の発生部位に関しても欧米と顕著な差がみられ る. 欧米では86 95\%の症例が S 状結腸を中心にみら れる8116)17)のに対し, 本邦では70 80\%の症例が右側結 腸に認められるとの報告が多い244)18)，自験例では右側 型 $58.6 \%$, 左側型が30\% と諸家の報告に比へ，右側型 が少なく左側型がやや多く認められた．欧米での圧倒 的左側優位の傾问には程遠いが，今後発見頻度の増加 とともに左側型の増加の可能性も示唆される。

年齢との関係では, 全息室症例の発見頻度が加齢々 とむに段階的に増加したが，これは加齢とともに左側 型が増加した結果とみなされ，左側型発症には後天的 要因が大きいことが推測された。これに対し右側型の 発見頻度には加龄の影響はなく，後天的要因が少ない と考えられた。

このように大腸㦝室症における本邦と欧米との大き な違いは発見頻度, 発生部位であるが, Stemmermann ${ }^{191}$ はハワイ在住の日系人の $52 \%$ という 高頻度に大腸悸室症を認め, 発生部位は日本人の発生 部位とほぼ同様で右側に多いと報告している。このこ とは憩室の発生頻度には食習慣などの生活様式が，発 生部位には人種差, 遺伝的な差などの先天的要因が, それぞれ関与していることを示唆するものとして興味 深い.

これらの大腸熄室症の臨床症状発現率は杉原ら ${ }^{3)}$ に よれば，輴室の存在部位とは無関係で，60\%が無症状 であるという。しかしその他の約 $40 \%$ は何らかの症状 を伴い，そのうち腸管の機能異常に基づく腹痛・腹満・ 便通異常など症状の軽度なるのが25\%に認められるは か, 喤室炎, 膿瘍形成, 㾇孔, 穿孔, 狭窄, 出血など の比較的重篤な㮩室合併症が約 $15 \%$ に併発するとされ る. 自験例でも後者に属する比較的重篤な数室合併症 を15.7\%に認めた。

次に大腸㮩室症の手術適応に関しては，ほとんど無 
症状のものに対しても症例によっては手術を行らべき との考方方を始めとして ${ }^{12220}$ 種々の基準が挙げられて いるが，著者らは大方の主張 ${ }^{49910121)}$ と同様の手術適応 基準を設けている.すなわち無症状のものはもちろん, 喤室に由来するものでる軽度の出血, 腹痛・腹満, 内 科的治療に良く反応する媳室炎などは手術適応はな く, 大量の出血, 穿孔による腹膜炎, 狭窄による通過 障害, 膿瘍形成を伴う息室炎, 反復する䕀室炎, 急性 虫垂炎や悪性隀瘍などとの鑑別が困難な場合などを適 応と考えている。この際特に左側の憩室に対しては, 池永ら9)指摘しているごとく，炎症を起こしてくる と壁の硬化や変形が強く生じたり，重篤な経過をとる ことが多いので, 㮩室炎所見が疑われる場合には積極 的に手術を施行すべきであろう。

上記の手術適応により手術を行った症例は22例で， 楻室症例に占める手術頻度は $15.7 \%$ あっあた。本邦に おける手術頻度は1.9 7.6\% ${ }^{344) 8}$ 之低率のもの之, $38 \sim 53.8 \%^{622223)}$ 之高率のものに分かれるが, このよう な手術頻度の大きな差は䕀室症例発見頻度と手術適応 の選択範囲の違い, さらには報告施設の有する特性, すなわち急性虫垂炎症例数の多寡など患者層の違い, その他に起因するすのと考えられる。自験例で手術頻 度が高かったのは急性虫垂炎との鑑別がつかずに手術 を施行した症例が 5 例に昇ったことも大きな要素と なっている。

手術に至った唕室合併症として注目すべきは右側型 の穿孔（4 例）と狭窄（1例）であった，穿孔は左側 型に多いとされているが9(13)21)24), 自験例の穿孔 6 例中 4 例が右側型にみられた. 大腸熄室は穿孔しても周囲 の腸管，大網，壁側腹膜などに括おわれて，限局性の

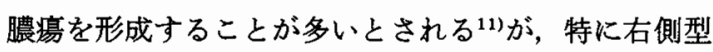
の 4 例中 1 例は大量の free air を伴 5沉発性腹膜炎を 呈していた。同様の病態は田中ら 25) 多報告している.元

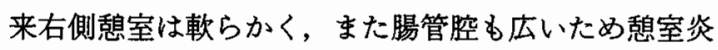
が腸管の全周性に生じない限り狭窄を秃こしにくいる されているが, 自験例では右側型に 1 例認められた。 この症例の場合, 唕室は単発であったが, 回盲弁のす ぐ近傍にあったため回盲弁を狭窄にいたらしめたもの と考えられる. 組織所見では, 粘膜固有層の浮腫とり ンパ組織の過形成, 笳層の肥厚, 浆膜下組織の fibrosis と abscess formation が認められ, 急性炎症所見と慢 性炎症所見が混在していた。

手術術式は, 秝室のひろがり, 合併症の所見, 患者 の全身状態, 術者の力量などにより種々の方法が選択
される，穿孔の場合，穿孔部の閉鎖，分割手術， 1 期 的腸切除吻合などさまざまな術式が工夫されている

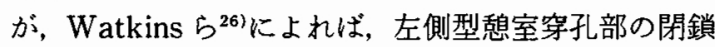
排膿の場合の死亡率は $53 \%$ ，穿孔部の閉鎖排膿と口側 においた covering colostomy 造設の死亡率は $35 \%$, 穿 孔部の exteriolizationの場合 $8 \%$ 腸切除の場合 $8 \%$ であったといい，可及的に病変部を切除すべきことを

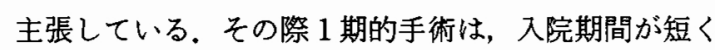
手術侵襲が 1 回ですむといら大きな利点がある一方で 吻合部縫合不全の発生など安全性の点で大きな難があ ることが指摘されている8 を始めとする栄養管理法や化学療法など近年の術後管 理技術の最近の進歩により，1期的な腸切除・吻合術 式の安全性が向上されつつあることも事実であ $3^{7) 13)}$. 今回の自験例でも右側型ではあるが 4 例の穿 孔例に対して, また $\mathrm{S}$ 状結腸䕀室穿孔を伴う両側型の 1 例に対して 1 期的に腸切除・吻合を行い，いずれも 術後経過は順調であった。 1 期的な切除・吻合術式で は術後縫合不全の危険が大きいと考方られる場合に は, covering colostomy を口側に扔くことが得策であ

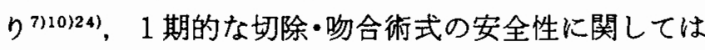
この covering colostomy の要否の判定も含め今後さ らに慎重に検討を重ねるつもりである。

悡室炎のらち左側型で重篤なるのの手術術式は穿孔 に準じて考えるが, 右側型, 特に急性虫垂炎との鑑別 が不可能で開腹され, 膿瘍形成を伴う螅室炎であるこ とが判明した場合の手術術式が問題となる。自験例で は 3 例にその様な症例を経験したが，諸家の報告3/4)9 ではドレナージのみ，あるいは虫垂切除とドレナージ のみで十分であるとの考え方が多い，その根拠は，(1) 右側型䄸公は限局性で穿孔などの重篤な合併症が少な い. (2)再然したり瘦孔を形成することも少ない. (3)腰 椎麻酔下であることが多いため手術侵襲は少ない方が 良い，などである。それに対し上西られは，(1)ドレナー ジのみでは腸瘦を形成する率が高い，(2)感染巣は除去 すべきである, (3)回盲部切除は腰椎麻酔下で手術可能 であり, 切除後合併症, 後遺症を認めなかった,など の理由により積極的な切除を推めている. 自験例では 明らかな膿瘍形成を伴った 4 例のうち 1 例は喤室炎に 伴う膿湯であるとの診断を得, 患者の強い希望で待期 的に腸切除を行ったが，残る 3 例が急性虫垂炎との鑑 別がつかず救急手術に至っている。 これら 3 例では唕 室切除あるいは腸切除を行い, 順調な経過をとって短 期間で退院した。前述のよらなドレナージ手術のみで 
は感染栄の消退と創の治瘜に腸切除よりも長期入院あ るいは通院治療を要する傾向があるし，ドレナージ後 腸㿉などが生じ 2 期手術を要する場合も皆無とは言党 ない.しかしドレナージといら小さな手術侵擎で治瘱 し亲るものに対して過大侵襲を加えるべきでないこと も明らかなため, 膿瘍を伴ら状況に遭遇した場合，ド レナージで止めるべきか，あるい腸切を行うべきか を術後経過の予測のもとに的確に見極める方策の検討 が必要と考兄ている，膿瘍に伴う腫瘤が悪性腫瘍と鑑 別のつかない場合もあろらが，その際にはドレナージ のみで手術を終点, 後日注腸, 大腸内視鏡などの検査 により診断を確立した上で，再手術の必要性を検討す ベきであろう.

両側型の反復する憩室炎例に対してとるべき術式に 関する報告は少ない, Leigh ら ${ }^{27)}$ は口側に惒室を取り 残した場合の再手術率は 5 年経過観察例で $3 \%$ \%あっ たという。京た Wolff ら ${ }^{28}$ は S 状結腸切除後口側大腸 に喤室の進行と症状の再然がみられたのは $4.9 \%$ にす ぎなかったと報告している。このように再燃例は少な いため，現時点では症状のある秘室密集部位の腸管を 区域切除する以外ないと考光ている.

\section{まとめ}

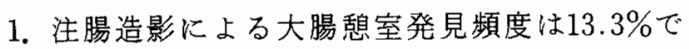
あった。そのうち左側型は $30 \%$ を占め従来の報告より も多く, 加龄とともに発見頻度が増加した。一方右側 型では年齢による影響をうけなかった。

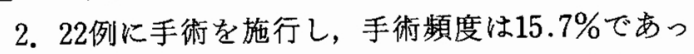

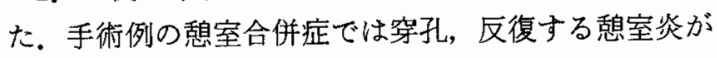
多くみられ，穿孔例 6 例中 4 例が右側型であった.

3. 穿孔に対する術式で 1 期的な腸切除・吻合術式は 安全性に難を伴うが利点も多い. 自験例では 5 例に施 行し良好な結果を得た. covering colostomy の要否の 判定も含め今後さらに慎重に 1 期的術式の適応につい て検討を重ねるべきと考劣る。

4. 右側型の膿瘍形成例に対してはこれまで 3 例腸 切除を行い良好な結果を得ているが，今後術後経過を 含めてドレナージ手術との慎重な比較検討が必要であ る.

\section{文 献}

1) Kubo A, Ishiwata J, Maeda $Y$ et al: Clinical studies on diverticular disease of the colon. Jpn J Med 22 : 185-189, 1983

2）井上幹夫, 吉田豊, 笹川 力汪か：大腸鄎室疾患 の疫学々臨床. 外科 $46: 1003-1010,1984$

3）杉原健一, 武藤徹一郎, 小西富夫汪か：大腸想室症
の治療。外科 $46: 1024-1028,1984$

4）野口友義, 長廻 紘, 高石 潔注か: 大腸鄎室炎. 臨内科 $1: 591-600,1986$

5) 長橋 捷, 山崎信行, 大井 玄: 食䭒瀻維摂取量と 大腸栃室症一ケース・コントロール・スタディ、日 街誌 $40: 781-788,1985$

6) 由井三郎, 兽和隔生, 橋本 化汪か：結腸悡室症の 臨床一自験13例を中心淿一外科 $38: 387-392$, 1976

7）歩内紀夫, 内山周也, 前田正之泀か：右側結腸想室 炎一手術症例40例についての検討. 臨外 35 ： 1341-1346, 1980

8) Rodkey GV, Welch CE: Changing patterns in the surgical treatment of diverticular disease. Ann Surg 200:466-478, 1984

9）池永遠雄, 桶上 駿, 沢田寿仁汪か：大腸复室症の 手術適応，胃之腸 $15: 825-832 ， 1980$

10）矢沢知海, 浜野恭一：大腸息室疾患. 外科的治療. 日本大腸肛門病会誌 $32: 518-523,1979$

11）牧野永城：手術の適応とタイミングー大腸鄎室 症. 臨外 $34: 875-879,1979$

12) Penford JCB: Management of uncomplicated diverticular disease by colonic resection in patients at st. Mark's Hospital 1964-1969. Br J Surg $60: 695-698,1973$

13）馬場正三：大腸憩宇症の外科. 外科診療 27 : 555-558, 1985

14）牧野惟義：消化管悡室について. 外科 23 ： 667-677, 1961

15）楨 殿順：われわれの経験した消化管鄎室の集計 について。 日臨外医会誌 $22: 186-187,1962$

16) Painter NS: Diverticular disease of the colion -A deficiency disease of wostern civilization. London, Williams Heinemann Medical Books Ltd, 1975, p175-179

17) Bockus HL: Gastroenterology, Vol. II, 3rd ed Philadelphia, Sunders, 1976, p973-1008

18）大森尚文, 秋本 伸, 亀岡信悟汪分: 大腸悡室症 一統計的考察一, 日本大腸肛門病会誌 32 : 502-511, 1979

19) Stemmermann GN, Yatani R: Diverticulosis and polyps of the large intestine-A necropsy study of Hawaii Japanese. Cancer $31: 1260$ $-1270,1973$

20）片岡 誠, 橋本隆彦, 飛岡紀彦活か：結腸愁室症手 術症例の検討. 外科治療 $52: 125-128,1985$

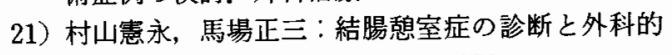
治療。手術 30 : 1067-1077, 1976

22）植松義和, 奈良圭司, 北条一宇汪か：右側型㮩室炎 の臨床的考察. 日本大腸肛門病会誌 $25: 27-28$, 1972

23）宮城伸二,世良田進三郎：自験結腸媓室45例の観 
察。日本大儤肛門病会誌 $25: 3-4,1972$

24）紙田位彦, 屋田善友, 金井正男注加：結渴鄎室症穿 孔例の検討. 外科診療 $21: 116-119,1979$

25）田中忠良, 宮原義門, 平田 元：右侧結躇息室症に 発生した盲腸賏室の造離腹腔内穿孔の一治検例。 外科診寮 $18: 964-968,1976$

26) Watkins GL, Oliver GA : Management of perforating sigmoid diverticulitis with diffusing peritonitis. Arch Surg $92: 928-933,1966$
27) Leight JE, Judd ES, Waugh JM : Diverticulitis of the colon-Recurrence after apparently adequate segmental resection. Am J Surg 103 : $51-54,1962$

28) Wolff BG, Ready RL, Mac Carty RL et al: Influence of sigmoid resection on progression of diverticular disease of the colon. Dis Colon Rectum 27 : 645-647, 1984 